\title{
Wood Colour Test of Fisherman's Boat on Microorganism Linkage in Kangean
}

\author{
Sri Nurhatika ${ }^{1}$ dan Awik Puji Dyah Nurhayati ${ }^{1}$
}

\begin{abstract}
Most of Indonesian fishermen have been using wooden boat. The boat has been used by fishermen in the north shore of East Java are made from Teak and Silk cotton tree. The leakage indication had not been shown on its linkage but on the boat caused by a microorganism called biofouling. The research used Colony Forming Unit method (CFU) and Saburoud Dextrose Agar (SDA) as a fungus counting medium and Nutient Agar (NA) as a bacteria counting medium. Each medium had been adjusted to the microorganism. The result shows that the wood and the paint which were used to build the boat influenced the type of microorganism, fungus, and bacteria on the boat. Bacteria preferred to stick on the yellow boat, and fungus preferred to stick on the green boat. The microorganism had been identified on the red Nyamplung tree, Kosambi tree, Jackfruit tree, Kamfer tree, and Teak tree are Micrococcus sp, Bacillus sp, and Pseudomonas sp, and all of those are bacteria. The other microorganism had been identified were Aspergillus niger, Aspergillus oryzae, Penicillium sp, Candida sp, Rhodotorulla sp, Saccharomyces sp, Verticillium sp, Paecilomyces sp, Monillia sp, and Altenaria sp, and all of those are fungus.
\end{abstract}

Keywords — Fungus, Settle Plate, Plate Count, CFU.

\section{PENDAHULUAN}

S ebagian besar nelayan di Indonesia masih menggunakan perahu kayu. Menurut Sudibyo [1] perahu nelayan di Pantai Utara Jawa Timur ada yang dibuat dari kayu jati dan kayu randu. Gejala kebocoran perahu nelayan terjadi justru bukan pada sambungannya, tetapi pada badan perahu yang disebabkan oleh penempelan bermacam-macam organisme atau biota laut, terutama mikroorganisme yang dikenal dengan sebutan Biofilm. Biofilm berkembang pada permukaan yang terbilas dalam lingkungan berair, baik permukaan biotik (tanaman atau binatang air), maupun abiotik (batu, logam dan ka$\mathrm{yu})$.

ZoBell [2] dalam penelitiannya menyebutkan bahwa bakteri pembentuk biofilm dari genus Pseudomonas, Vibrio, Bacillus, Flavobacterium, Micrococcus, Achromobacter, dan Bacterium dapat secara cepat melekat pada benda yang dimasukkan ke kolom air daripada benda yang diapungkan. Hampir semua anggota jenis Gallionella, Sideromonas, Siderocapsa, dan Caulobacter tumbuh pada permukaan padat yang ada di dalam kolom air laut.

Naskah diterima pada tanggal 2 Maret 2009, selesai revisi pada 14 Mei 2009

${ }^{1}$ Sri Nurhatika dan Awik Puji Dyah Nurhayati adalah dosen Program Studi Biologi, FMIPA, Institut Teknologi Sepuluh Nopember, Surabaya, INDONESIA

e-mail : nurhatika@bio.its.ac.id
Pelapukan biologis merupakan masalah yang serius, karena terjadinya penempelan organisme-organisme dapat merusak perahu-perahu, alat-alat maupun kapal-kapal. Penempelan (biofouling) dimulai dari bakteri yang menempel dan melapisi permukaan alat sampai avertebrata yang mempunyai kemampuan merusak dan memakan permukaan tersebut. Larva avertebrata menempel pada permukaan berbagai benda setelah benda itu dilapisi oleh bakteri. Ternyata tanpa adanya bakteri tersebut metamorfosis avertebrata tidak terjadi. Seringkali penempelan suatu jenis bahan pada perahu akan merangsang jenis lain untuk menempel, sehingga mempertebal lapisan menyebabkan perahu mendapat beban tambahan.

Cahaya yang dapat mengeluarkan bermacam macam warna sangat berpengaruh pada proses pertumbuhan bakteri. Umumnya cahaya merusak sel mikroorganisme yang tidak berklorofil. Sinar ultraviolet dapat menyebabkan terjadinya ionisasi komponen sel yang berakibat menghambat pertumbuhan atau menyebabkan kematian. Pengaruh cahaya terhadap bakteri dapat digunakan sebagai dasar sterilisasi.

Perahu atau kapal kayu mempunyai peranan penting dalam perkembangan mikroorganisme dan cypris yang pada akhirnya dapat merusak kondisi perahu karena penempelannya tersebut. Barnes (1994) menyebutkan, bahwa kapal yang kotor karena ditempeli oleh mikroorganisme dan cypris bisa berkurang kecepatannya sampai $30 \%$.

Berdasarkan asumsi bahwa pelekatan mikroorganisme dan cypris dpengaruhi oleh warna dan jenis substrat sebagai tempat pelekatannya, maka permasalahan dalam penelitian ini adalah bagaimana pengaruh warna (merah, kuning, hijau, biru) dan jenis kayu (kesambi, kamfer, jati, nyamplung, dan nangka) terhadap pelekatan mikroorganisme.

Penelitian ini bertujuan untuk mengetahui jenis kayu dan warna sebagai badan perahu yang tidak mudah rusak karena adanya mikroorganisme, bakteri dan jamur, yang menempel pada badan perahu.

\section{Metode Penelitian}

Waktu dan Tempat Penelitian. Penelitian dilakukan di Laboratorium Mikrobiologi ITS dan Laboratorium Biologi UNAIR pada bulan Juni-Juli 2007. Lokasi pengambilan sampel adalah Pantai Kangean, Sumenep, Madura.

Persiapan Penelitian. Penyiapan bagan tempat kayu di laut dan penyiapan kayu yang akan di uji.

Kayu yang akan di uji adalah kayu nyamplong, kosambi, nangka, kamper dan jati masing masing dengan ukuran panjang $25 \mathrm{~cm}$, lebar $10 \mathrm{~cm}$ dan tebal $2 \mathrm{~cm}$. Sepanjang 2,5 cm dari sisi tengah atas dan bawah dilubangi dengan diameter $0,5 \mathrm{~cm}$ untuk memaukan tali yang diguna- 
kan untuk mengikat kayu pada paralon. Selanjutnya di cat warna merah, kuning, hijau, biru, dan kontrol tanpa diberi warna; didiamkan selama 1 minggu untuk mendapatkan cat yang benar-benar kering merata. Setelah 1 minggu, kayu dipasang pada beton berukuran panjang 3 meter dengan garis tengah 12 milimeter. Diantara dua kayu dibatasi dengan pipa paralon PVC sepanjang 10 $\mathrm{cm}$ dengan garis tengah 1 inci.

Urutan pemasangan dimulai dari kayu yang di cat dengan warna biru $(490,549 \mathrm{~nm})$, kuning $(605,857$ $\mathrm{nm})$, merah $(681,593 \mathrm{~nm})$ hijau $(400,700 \mathrm{~nm})$, dan kontrol (kayu yang tidak di cat).

Pelaksanaan Penelitian. Pemasangan papan di 3 stasiun dengan replikasi pada jarak sekitar $500 \mathrm{~m}$ dari garis pantai dengan teluk 0,5 $\mathrm{m}$ dari permukaan laut. Data variable pendukung (suhu, $\mathrm{pH}$, dan salinitas) diambil setiap hari.

Isolasi mikroorganisme dari papan kayu ke medium. Identifikasi mikroorganisme dengan melakukan pengamatan morfologi dan uji mikrokopis.

Pembuatan Isolat Murni Jamur. Setelah koloni jamur dihitung, kemudian dibuat isolat murninya. Isolat murni dibuat dengan sub kultur. Subkultur dengan menginokulasi koloni pada media saburoud dextrose agar miring sampai diperoleh isolat tunggal atau isolat murni.

Pengamatan Makroskopis Koloni Jamur (Isolat Murni). Untuk pengamatan ciri makroskopisnya maka setiap satu isolat murni jamur diinokulasi kedalam satu media agar datar kemudian diinkubasi pada suhu $29,5^{\circ}$ C. Ciri makroskopis jamur yang diamati meliputi: warna permukaan koloni, warna bagian dasar koloni (reverse side), perubahan warna selama pengamatan, garisgaris radial dari pusat koloni ke arah tepi koloni, tetestetes air (eksudat), lingkaran-lingkaran konsentris, diameter koloni, tekstur koloni dan topografi koloni

Tekstur koloni jamur yang diamati adalah: cottony atau woolly (koloni seperti kapas) dengan miselium aerial yang tebal, velvety (koloni dengan sedikit miselium aerial) dan glanular atau powdery (koloni seperti bubuk gula atau tepung).

Topografi koloni jamur yang diamati adalah: rugose (lipatan) yang dalam dan tidak teratur dari tengah koloni (deep radial irregular furrow), umbonate (bulatan) pada tengah koloni dan biasanya disertai dengan bentuk rugose dan verrucose (lipatan) dengan permukaan tergulung.

Pembuatan Slide culture. Slide culture digunakan untuk pengamatan ciri mikroskopis. Pembuatan slide culture dilakukan berdasarkan Benson (1998) dan Kern (1985) yaitu: kertas saring steril diletakkan pada bagian dasar cawan petri steril secara aseptik dengan menggunakan penjepit. Batang gelas steril berbentuk "U" diletakkan diatas kertas saring (batang gelas dapat disterilisasi dengan pemanasan diatas api bunsen jika dipegang dengan penjepit). Kaca obyek steril kemudian diletakkan diatas batang gelas steril berbentuk " $U$ " dengan penjepit. Akuades $4 \mathrm{ml}$ dituang pada kertas saring. Scapel disterilisasi diatas api Bunsen kemudian media saburoud agar dipotong berbentuk kotak $1 \mathrm{~cm} \times 1 \mathrm{~cm}$. Potongan agar diangkat dengan menyelipkan scapel pada satu sisinya. Jarum inokulasi disterilisasi diatas api Bunsen. Isolat murni dicuplik dengan jarum inokulasi steril kemudian ditusukkan ke bagian tengah potongan agar dan empat sisi yang lain kemudian di tutup dengan kaca penutup steril. Slide culture kemudian diinkubasi pada suhu kamar $\left(25^{\circ} \mathrm{C}\right)$ selama 48 jam.

Setelah jamur bersporulasi maka dilakukan pewarnaan dengan pewarna lactophenol cotton blue (LPCB). Gelas penutup pada slide culture diambil dan ditetesi etanol 95\%. Pewarna lactophenol cotton blue (LPCB) diteteskan ke kaca obyek steril. Gelas penutup diletakkan pada kaca obyek. Etanol pada gelas penutup akan berevaporasi sehingga jamur bercampur dengan LPCB. Slide ini siap diamati di bawah mikroskop dengan perbesaran 100-400 kali. Kaca obyek pada slide culture ditetesi etanol 95\% diikuti dengan meneteskan LPCB kemudian ditutup dengan gelas penutup steril. Slide ini siap diamati dibawah mikroskop binokuler dengan perbesaran 100-400 kali. Kedua slide dapat dibandingkan sehingga satu slide mungkin lebih baik dari yang lain. Gambar jamur kemudian difoto dengan mikroskop foto.

Pengamatan mikroskopis. Slide culture diamati dibawah mikroskop untuk melihat bentuk dan warna tubuh jamur. Ciri mikroskopis jamur yang diamati adalah hifanya bersekat atau tidak, hifanya berwarna atau tidak dan bentuk sporanya.

Identifikasi Jamur. Jamur yang telah diamati kemudian diidentifikasi dengan menggunkan kunci identifikasi sampai tingkat genus dengan kunci identifikasi Mc Ginnis (1980). Identifikasi jenis Aspergillus dengan kunci identifikasi Gandjar (1999). Identifikasi jenis jamur lain mengunakan Larone (1993).

Pengukuran Faktor Lingkungan di Perairan Kangean. Faktor lingkungan yang diukur pada setiap pengambilan sampel adalah suhu, $\mathrm{pH}$, salinitas dan kecepatan angin.

Analisa Data. Untuk mengetahui pengaruh perlakuan warna perahu dan jenis kayu terhadap penempelan mikroorganisme (bakteri dan jamur) dilakukan analysis of varians (ANOVA) dengan taraf kepercayaan 95\%. Pada penelitian ini tidak dibedakan jenis-jenis bakteri dan jamur pada masing-masing warna tetapi dalam bentuk konsorsium mikroorganisme. Apabila berbeda nyata maka dilanjutkan dengan uji BNT dengan $\alpha=5 \%$. Hasil identifikasi jamur dianalisa secara deskriptif (Gaspersz, 1991).

\section{HASIL DAN PEMBAHASAN}

Cahaya sangat berpengaruh pada proses pertumbuhan bakteri. Umumnya cahaya merusak sel mikroorganisme yang tidak berklorofil. Sinar ultraviolet dapat menyebabkan terjadinya ionisasi komponen sel yang berakibat menghambat pertumbuhan atau menyebabkan kematian. Pengaruh cahaya terhadap bakteri dapat digunakan sebagai dasar sterilisasi.

Hasil penelitian menunjukkan bahwa dalam tiap kayu dengan cat warna tertentu terdapat populasi mikroorganisme yang terdiri dari tiga jenis bakteri dan sepuluh jenis jamur. Secara rinci dapat dilihat pada Tabel 1. 
TABEL 1

JENIS-JENIS BAKTERI DAN JAMUR YANG DITEMUKAN PADA LIMA MACAM KAYU DENGAN LIMA MACAM WARNA YANG BERBEDA

\begin{tabular}{|c|c|c|c|}
\hline \multirow{2}{*}{ Jenis Kayu } & \multirow{2}{*}{ Warna Cat } & \multicolumn{2}{|c|}{ Hasil Identifikasi } \\
\hline & & Bakteri & Jamur \\
\hline Nyamplung & $\begin{array}{l}\text { Tanpa cat } \\
\text { (kontrol) }\end{array}$ & Micrococcus, Bacillus, Pseudomonas & Aspergillus niger \\
\hline Nyamplung & Merah & Pseudomonas & Aspergillus niger \\
\hline Nyamplung & Kuning & Micrococcus, Bacillus, Pseudomonas & $\begin{array}{l}\text { Aspergillus niger, Rhodotorula, } \\
\text { Candida, Saccharomyces, } \\
\text { Penicillium }\end{array}$ \\
\hline Nyamplung & Hijau & Micrococcus, Pseudomonas & $\begin{array}{l}\text { Aspergillus niger, Aspergillus } \\
\text { oryzae, Penicillium, Candida }\end{array}$ \\
\hline Nyamplung & Biru & Bacillus, Pseudomonas & Aspergillus niger \\
\hline Kosambi & $\begin{array}{l}\text { Tanpa cat } \\
\text { (control) }\end{array}$ & Pseudomonas, Bacillus & $\begin{array}{l}\text { Penicillium, Venicillium, } \\
\text { Paecilomyces Aspergillus niger, } \\
\text { Candida }\end{array}$ \\
\hline Kosambi & Merah & Pseudomonas, Bacillus & $\begin{array}{l}\text { Saccharomyces, Candida, } \\
\text { Rhodotorula, Aspergillus niger }\end{array}$ \\
\hline Kosambi & Kuning & Pseudomonas, Bacillus, Micrococcus & Aspergillus niger \\
\hline Kosambi & Hijau & Pseudomonas, Bacillus, Micrococcus & $\begin{array}{l}\text { Aspergillus niger, Candida, } \\
\text { Rhodotorula, Penicillium }\end{array}$ \\
\hline Kosambi & Biru & Pseudomonas, Bacillus, Micrococcus & Aspergillus niger, Candida \\
\hline Nangka & $\begin{array}{l}\text { Tanpa cat } \\
\text { (control) }\end{array}$ & Bacillus, Micrococcus, Pseudomonas & $\begin{array}{l}\text { Momillia, Aspergillus niger, } \\
\text { Candida }\end{array}$ \\
\hline Nangka & Merah & Pseudomonas, Bacillus & $\begin{array}{l}\text { Rhodotorula, Aspergillus niger, } \\
\text { Candida }\end{array}$ \\
\hline Nangka & Kuning & Micrococcus, Bacillus, Pseudomonas & Momilia, Altervaria, Penicillium \\
\hline Nangka & Hijau & Pseudomonas, Bacillus & Rhodotorula, Candida \\
\hline Nangka & Biru & Pseudomonas, Bacillus & $\begin{array}{l}\text { Aspergillus niger, Altervaria, } \\
\text { Penicillium }\end{array}$ \\
\hline Kamfer & $\begin{array}{l}\text { Tanpa cat } \\
\text { (control) }\end{array}$ & Pseudomonas, Bacillus & Aspergillus niger, \\
\hline Kamfer & Merah & Pseudomonas, Bacillus & Aspergillus niger, Penicillium \\
\hline Kamfer & Kuning & $\begin{array}{l}\text { Micrococcus, } \\
\text { Pseudomonas, Bacillus }\end{array}$ & Candida, Aspergillus niger \\
\hline Kamfer & Hijau & $\begin{array}{l}\text { Micrococcus, } \\
\text { Pseudomonas, Bacillus }\end{array}$ & $\begin{array}{l}\text { Aspergillus niger, } \\
\text { Saccharomyces, Candida }\end{array}$ \\
\hline Kamfer & Biru & Pseudomonas, Bacillus & $\begin{array}{l}\text { Aspergillus niger, Candida, } \\
\text { Saccharomyces }\end{array}$ \\
\hline Jati & $\begin{array}{l}\text { Tanpa cat } \\
\text { (control) }\end{array}$ & Pseudomonas, Bacillus & Aspergillus niger \\
\hline Jati & Merah & Bacillus, Pseudomonas & $\begin{array}{l}\text { Aspergillus niger, } \\
\text { Saccharomyces, Candida }\end{array}$ \\
\hline Jati & Kuning & Bacillus, Pseudomonas, Micrococcus & $\begin{array}{l}\text { Aspergillus niger, Candida, } \\
\text { Saccharomyces }\end{array}$ \\
\hline Jati & Hijau & Bacillus, Pseudomonas & Candida, Aspergillus niger \\
\hline Jati & Biru & Pseudomonas, Bacillus & $\begin{array}{l}\text { Saccharomyces, Aspergillus } \\
\text { niger, Rhodotorula }\end{array}$ \\
\hline
\end{tabular}

Pengaruh mikroorganisme terhadap keawetan kayu. Keawetan kayu adalah daya tahan sesuatu jenis kayu terhadap organisme rusak kayu. Tambunan dan Nandika [3] menyatakan bahwa perusakan kayu dapat terjadi oleh berbagai faktor baik biologis, fisik, mekanisme maupun kimia. Kenyataan menunjukkan bahwa dari keempat faktor tersebut, ternyata paling banyak menimbulkan kerusakan terhadap kayu adalah faktor biologis. Faktor-faktor biologis perusak kayu yang terpenting adalah jamur, bakteri, serangga dan binatang laut. Jasad hidup tersebut merusak kayu karena mereka menjadikan kayu sebagai tempat tinggal atau makanannya. Kerugi- an yang terjadi akibat kerusakan kayu oleh faktor biologis tiap tahunnya mencapai milyaran rupiah. Kerusakan tersebut terjadi baik pada pohon yang masih berdiri, balok segar, kayu gergajian, maupun produk-produk kayu lain dalam penyimpanan dan pemakaian.

Bakteri. Jenis kayu dan warna sangat berpengaruh pada proses pertumbuhan bakteri. Pada kayu jati dan kayu nyamplung tanpa warna penempelan bakteri paling kecil (Tabel 1). Menurut Anonim [4], kayu jati merupakan kayu kelas satu karena kekuatan, keawetan dan keindahannya. Sedangkan nyamplung merupakan kayu terbaik yang tersedia banyak di Sumenep. 
Warna kuning pada kayu menyebabkan penempelan bakteri paling banyak. Warna lazim diidentifikasikan dengan panjang gelombang. Kuning dengan panjang gelombang $857 \mathrm{~nm}$ merupakan panjang gelombang yang besar sehingga mampu menarik bakteri lebih banyak untuk melakukan penempelan karena panjang gelombang tersebut sesuai dengan panjang gelombang yang dikeluarkan oleh bakteri. Terdapat tiga jenis bakteri yaitu Miccroccus sp, Bacillus sp dan Pseudomonas sp. Knuht (1969) dalam penelitiannya menjelaskan dari 198 jenis bakteri yang merusak kayu maka yang terbesar dari golongan bacillus, Aerobacter sp dan Pseudomonas sp.

Hunt dan Garrat [5] dalam penelitiannya terhadap bahan-bahan dari kayu, telah menemukan 198 jenis bakteri pada berbagai jenis kayu. Diantaranya dari genus Bacillus, Aerobacter, dan Pseudomonas yang biasanya hidup didalam tanah dan air [3]. Nicholas (1987) menyatakan bakteri ini masuk kedalam kayu bagian dalam dengan jalan menembus sel yang satu ke sel yang lainnya melalui noktah sel, setelah penghancuran membran sel. Serangan bakteri terhadap kayu biasanya terjadi bersama-sama dengan jamur [3]. Hunt dan Garrat [5] menyatakan kedua jenis jasad renik tersebut kemungkinan bekerjasama dalam penghancuran kayu secara biologis. Bakteri mempunyai kemampuan dalam merusak selulosa kayu dan juga mampu merusak jaringan-jaringan berlignin jika kondisi lingkungan memungkinkan. Kayu yang diserang oleh bakteri akan banyak menyerap air dan kekuatan kayu akan berkurang. Pada prinsipnya serangan bakteri menyebabkan daya ahorsi pada kayu menjadi tidak normal karena rusaknya membran noktah dari sel-sel [3].

Jamur. Pada kayu jati, kayu nyamplung dan kayu kamfer tanpa warna penempelan jamur paling kecil. Warna hijau pada kayu menyebabkan penempelan jamur paling banyak, Febdian (2006) warna hijau yang memiliki panjang gelombang $700 \mathrm{~nm}$ merupakan campuran warna kuning dan biru, menyebabkan panjang gelombang yang dapat ditangkap oleh golongan jamur. Terdapat 10 jenis jamur yaitu Aspergillus niger, Aspergillus oryzae, Penicillium sp, Candida sp, Rhodotorula $\mathrm{sp}$, Saccharomyces sp, Verticillium sp, Paecilomyces sp, Monilla sp dan Alternaria sp.

Komponen karbohidrat dan lignin kayu memberikan makan pada variasi cendawan yang luas [6]. Nicholas (1987) menyatakan tenaga dan kebanyakan dari bahanbahan sel bagi organisme itu dipenuhi terutama oleh karbohidrat yang terdiri dari holoselulosa, pati, dan gula serta untuk beberapa organisme oleh lignin. Nitrogen dan mineral-mineral tersedia meskipun dalam jumlah yang terhitung kecil. Sejumlah kecil thiamin, vitamin B1 dari nutrisi binatang, tampaknya diperlukan oleh kebanyakan cendawan. Tambunan dan Nandika [3] menyatakan komponen-komponen tersebut dirombak secara biokimia dengan bantuan enzim. Karena perombakan inilah maka sifat-sifat kayu berubah dan cenderung rusak.

Mikroorganisme ini dapat dibedakan dalam empat golongan tergantung pada sifat perkembangan didalam dan pada kayu, dan tipe kerusakan yang ditimbulkan olehnya. Hunt dan Garrat [5] menyatakan golongangolongan tersebut adalah cendawan perusak kayu, pewarna kayu, cendawan buluk dan bakteri penyerang kayu.

Pengaruh serangan jamur terhadap sifat-sifat kayu secara umum adalah: 1). Pengaruh berat, hilangnya sebagian selulosa dan lignin karena dirombak oleh jamur. Bila presentase penyerangan jamur ini tinggi, maka kayu menjadi semakin ringan. 2). Pengaruh kekuatan, kayu yang diserang jamur akan mempengaruhi sifat keteguhan pukul, keteguhan lengkung, keteguhan tekan, kekerasan serta elastisitasnya dan mengakibatkan kekuatan kayu akan berkurang. 3). Peningkatan kadar air, kayu yang lapuk mengandung air lebih banyak dari pada kayu yang segar sehat sehingga menjadi media yang baik untuk penempelan mikroorganisme. 4). Penurunan kalori, nilai kalori ada hubungannya dengan intesitas serangan. Apabila intensitas pelapukan semakin tinggi maka nilai kalori semakin kecil, sebab kayu yang lapuk memberikan panas yang lebih kecil dari pada kayu yang sehat. 5). Perubahan warna, white-rot menimbulkan warna putih, brown-rot menimbulkan warna coklat, sedangkan bluestain menimbulkan warna hitam kebiru-biruan. Pada warna-warna cerah misalnya warna kuning yang memiliki panjang gelombang yang sesuai dengan kebutuhan hidup mikroorganisme (khusus untuk bakteri dan jamur) 6). Perubahan struktur mikroskopis, white-rot menyebabkan dinding sel kayu makin lama- makin tipis dan akhirnya habis. Brown-rot menyerang selulosa kayu. Soft-rot hanya menyerang diding sekunder dan bila dilihat dengan mikroskop polarisasi maka terlihat lubang-lubang spiral yang memanjang.

\section{KESIMPULAN}

Jenis kayu dan cat warna yang digunakan dalam pembuatan badan kapal mempengaruhi jenis mikroorganisme, jamur dan bakteri, yang menempel. Mikroorganisme yang ditemukan pada kayu nyamplung, kosambi, nangka, kamfer, dan jati yang dicat dengan warna merah, kuning, hijau, biru dan tanpa cat warna sebagai kontrol adalah 3 jenis bakteri yakni Micrococcus, Bacillus, dan Pseudomonas dan 10 jenis jamur yakni Aspergillus niger, aspergillus oryzae, Penicillium, Candida, Rhodotorulla, Saccharomyces, Verticillium, Paecilomyces, Monillia, dan Altenaria.

\section{DAFTAR PUSTAKA}

[1] Sodibyo. 1988. "Uji Pengaruh Jenis, Tekstur dan Pelapisan Terhadap Kemunculan Biofouling Pada Kayu Bahan Pembuat Perahu Nelayan". FMIPA Unair. Surabaya.

[2] Zo Bell and Upham, 1944. Brevibacterium stationis.http://nbimcc.hit.bg/Bacteria/Brevibacterium\%20stationis.html. [25 Mei 2009]

[3] Tambunan, B. dan D. Nandika. 1989. "Deteriorasi kayu oleh faktor biologis". Pusat Antar Universitas Bioteknologi. IPB Bogor.

[4] Anonim. 2007. "Fungus Description". www.doctorfungus.org. 27 September 2007Barnes. R. 1984. Invertebrate Zoology, $3^{\text {rd }}$. W.B. Saunders Company, Toppan Company Ltd. Tokyo. P 541-552

[5] Hunt, G.M. dan G.A. Garrat. 1986. "Pengawetan kayu". Edisi 1 Diterjemahkan oleh Jusuf, M. Akademika pressindo. Jakarta.

[6] Haygreen, J.G dan J.L. Bowyer. 1993. "Hasil hutan dan ilmu kayu, suatu pengantar". Diterjemahkan oleh Hadikusumo, S.A. Gadjah Mada University Press. Yogyakarta. 